\title{
Varga Balázs
}

\section{Filmek, tömegek, kultúrák. Két új oktatási segédanyagról}

\section{Szerzô}

Varga Balázs az ELTE BTK Filmtudomány Tanszékének adjunktusa. Kutatási területe a modern és kortárs magyar film, a kortárs európai film, a filmes társadalom- és intézménytörténet. A Metropolis folyóirat alapító szerkesztóje.

https://doi.org/10.31176/apertura.2018.13.1.12 


\section{Varga Balázs}

\section{Filmek, tömegek, kultúrák. Két új oktatási segédanyagról}

[Füzi Izabella - Török Ervin: Elbeszélés a tömegkultúra korában. Digitális tananyag. Szeged, 2016; Virginás Andrea: A kortárs tömegfilm (tömegkultúra, müfajok, médiumok) - Egyetemi jegyzet. Kolozsvár, Ábel Kiadó, 2016. 132 oldal]

Az oktatási segédanyag sajátosan hibrid típusú írásmú. A tudományos szakszöveg és az ismeretterjesztés találkozik, keveredik benne - szerzôtól, felhasználási módtól vagy tudományterülettôl függôen más és más arányban. Egy oktatási segédanyag írójának nemcsak a maga kutatási területét kell alaposan ismernie, hanem tisztában kell lennie a célközönség elvárásaival, ismereteivel is. Meg kell találnia azt a hangot, stílust és regisztert, amelyben az adott témával kapcsolatos kérdéseket érdemi módon tudja áttekinteni, szintetizálni és közérthetôen megfogalmazni. Mindezzel együtt az oktatási segédanyagok az adott kutatási terület helyzetérôl, legfontosabb aktuális kérdéseiról és vitáiról is beszámolhatnak, adott esetben naprakész kontextusban elhelyezve a „kötelezô” tananyagot.

Az alábbiakban két, nemrég megjelent magyar nyelvú oktatási segédanyagról lesz szó, melyeket tematikus kapcsolódási pontjaikat kihasználva igyekszem össze is vetni egymással. Füzi Izabella és Török Ervin online elérhetô anyaga, az Elbeszélés a tömegkultúra korában a Szegedi

Tudományegyetemen készült, szerzôi az ottani Vizuális Kultúra és Irodalomelmélet Tanszék oktatói. Virginás Andrea egyetemi jegyzete, A kortárs tömegfilm (tömegkultúra, müfajok, médiumok) pedig a Sapientia Erdélyi Magyar Tudományegyetem Filmmúvészet, fotómúvészet, média szakján tartott kurzusokból nôtt ki, és a kötetet a kolozsvári Ábel Kiadó adta ki magyar nyelven. 
Ezek az intézményi kontextusok oktatási segédanyagok esetében különösen fontosak: mindkét esetben a magyar nyelvú filmes felsôoktatás meghatározó múhelye adja a hátteret, és mindkét anyag szerzôi az akadémiai világban jegyzett és egyben egyetemi oktatóként is aktív szereplôi a színtérnek. Olyan szerzôk, akik mind a magyar nyelvú filmtudomány, mind a magyar nyelvú filmes képzés helyzetével és problémáival tisztában vannak. Virginás bevezetôje pontosan meg is nevezi azokat a kurzusokat, amelyek a kötet alapját (elôtörténetét) adják, így világosan látható,hogy milyen módon formálódott vagy tesztelődött az anyag; de a Füzi-Török páros szövege isannak megjelölésével kezdôdik, hogy milyen képzési formák és kurzusok lehetnek az elsôdleges célpontjai és felhasználói a leckéknek. A tizenkét fejezetre való tagolás már önmagában jelzi, hogy az egyetemi féléves kurzusok adhatják meg az elsődleges felhasználási keretét ezeknek az oktatási anyagoknak. Ez persze csak lehetôség, és mivel a különbözố intézményekben eltérô curriculumok mentén, eltérố tárgyfelosztásban zajlik a munka, az adaptálás kérdése (ki, hol, mikor, kinek, miért és mit fog használni belölük) elég nagy szabadságot jelent.

Magával a múfajjal kapcsolatban még egy dolgot fontos elöre bocsátani: a tananyag vagy jegyzet meghatározás magában hordoz egyfajta finom behatárolást is. Nem kíván és nem is tud mindenre kitérni. Bizonyos dolgokat csak vázlatosan érint vagy foglal össze, önmagát pedig nagyon hangsúlyosan más típusú szövegek kontextusába utalja, illetve ebben a kontextusban pozicionálja (mi az, amirôl bôvebben, a hallgatók, olvasók számára is elérhetô helyen és érthetôen írtak már). A segédanyag, tananyag vagy jegyzet tehát alapvetôen praktikumvezérelt és nem önmagában álló, nem önmagáért való szöveg. Ezeket a behatárolásokat mint szempontokat igyekszem nem elfelejteni: én is egyetemi oktatóként, potenciális felhasználóként próbálok tekinteni az itt bemutatott két tananyagra.

Mindkét munka érdekességét és jelentôségét az adja, hogy a kortárs mozgóképkultúra trendjeit segítenek értelmezni. Jóllehet a két tananyagban tárgyalt kérdések és témák majd mindegyikérôl magyar nyelven is akadnak elérhetô elemzések és tanulmányok, tananyag vagy ismeretterjesztő összefoglalás e tárgyakban még nem született.

Füzi Izabella és Török Ervin tananyaga betekintést nyújt a tömegkultúra elméleteibe, majd a népszerú irodalom három fontos múfaját (sci-fi, krimi, kortárs szingliregény) mutatja be példaelemzések révén. Ezeket a fejezeteket Török Ervin jegyzi. ${ }^{[1]}$ A második blokkban, melyet Füzi Izabella írt, a tömegfilmes elbeszélés sajátosságainak jellemzése után a klasszikus, illetve posztklasszikus narratíva kerül elô, szintén példaelemzések révén. Végül a kortárs televíziós sorozatok világa is megidézôdik, mégpedig a narratív komplexitás kérdése kapcsán.

Virginás Andrea jegyzete szintén a tömegkultúra elméleti keretei között helyezi el a tömegfilmet. Az ô anyaga azonban csak a filmkultúrára koncentrál, és az elmúlt negyven év tendenciáit tekinti át, különös tekintettel az analóg-digitális váltásra és annak múfaji-, stiláris és kulturális vonatkozásaira.

Recenziómban néhány olyan vonatkozást emelek ki, amelyek mentén egymással is össze lehet 
hasonlítani a két tananyagot. Három kérdéskörrôl és egy módszertani vonatkozásról lesz szó. A tömegkultúra és a populáris kultúra lehatárolásának és értelmezéseinek a kérdésérôl, a múfajiságról, illetve a kortárs / posztklasszikus film jellemzéséról, közelebbrôl a kortárs film és a látványosság, valamint a digitális kultúra viszonyáról. A módszertani probléma pedig az, hogy a filmelemzések, a példák és illusztrációk hogyan jelennek meg, miként épülnek be az egyes szerzók anyagaiba, érvelésmódjába.
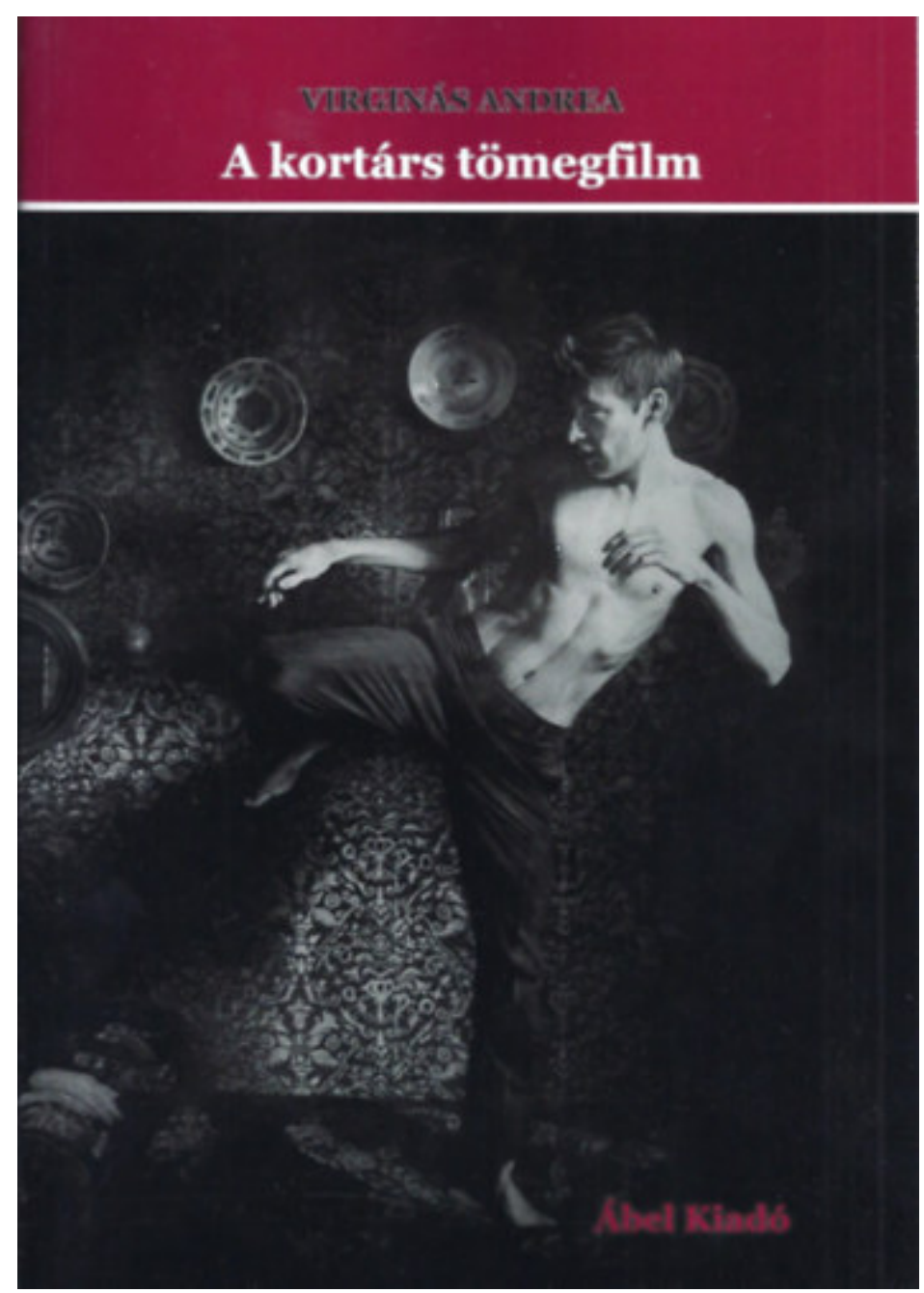

Virginás Andrea: A kortárs tömegfilm (tömegkultúra, müfajok, médiumok) - Egyetemi jegyzet

\section{Kritikus tömegek}

A tömeg szó mindkét anyag címében szerepel - az egyikben a tömegkultúra, a másikban a tömegfilm. A filmkultúra újrapozícionálása és elhelyezése a tömegkultúra kontextusában az egyik leglényegesebb aspektusa ezeknek a tananyagoknak. ${ }^{[2]}$ Tömegfilm, populáris film, népszerú film, szórakoztató film, múfaji film, mainstream, avagy fôsodorbeli film, hollywoodi film - ezek nem egymással felcserélhetố kategóriák. Sem angolul, sem magyarul. A filmtudományi és kultúratudományi diskurzusban is folyamatosan vitatott definíciókról van szó. A fogalomtisztázás 
elsô lépése tehát nélkülözhetetlen - és mindkét szöveg, lehetôségeihez mérten, erôteljesen reflektál erre a problémára.

Virginás Andrea a tömegkultúra kialakulásával, meghatározásával és jellemzőivel kapcsolatban egészen különböző vonatkozásokat és szempontokat hoz elô, így viszont nehéz megtalálni a fókuszt az érvelésében. A bevezetôben a „brit kultúratanulmányokra” hivatkozik. A cultural studies magyarul ugyan inkább kritikai kultúrakutatás néven szokott elókerülni (esetleg lehetne, meg szokás is kultúratudományként szerepeltetni), de ez végsô soron kevéssé zavaró. Nagyobb probléma, hogy a szöveg szinonimaként használja a tömegkultúra és a populáris kultúra fogalmakat (11.), amivel egy fontos megkülönböztetés, és annak elméleti-történeti hozadéka is elvész. A populáris kultúra tágabb fogalom, mint a tömegkultúra. A tömegkultúra újkori fejlemény, kialakulása (ahogy azt Virginás is írja) az ipari forradalom utáni városiasodáshoz és a modern tömegtársadalmak kialakulásához köthetô. Különböző „kritikus tömegek” együttes jelenléte adja a tömegkultúra lényegét: tömeges gyártás, tömeges terjesztés és tömeges fogyasztás. A népszerúség (popularitás) önmagában még nem elégséges feltétele a tömegkultúrának - ezért is beszélhetünk arról, hogy a populáris kultúra tágabb fogalom, mint a tömegkultúra. Mindezeket a kérdéseket szisztematikusan tárgyalja Noël Carroll A tömegmúvészet filozófiája címú, 1998-as könyvében ${ }^{[3]}$ (tanulságos, hogy Carroll tömegmúvészetrôl és nem tömegkultúráról beszél). Azért merem iderángatni az amerikai analitikus múvészetfilozófust, mert amúgy Virginás is rá hivatkozik, sôt, egy ponton azt írja, hogy át is veszi Carroll tömegkultúra/tömegmúvészet definícióját (12). Hozzáteszem, Virginás annyiban nagyon következetes, hogy a tömegkultúra egyik specifikumaként, Carrollra építve, kiemelten tárgyalja a tömegtechnológiák, azaz a tömeges terjesztés kérdését - a modern nyomdatechnikáktól a kortárs digitális platformokig.

Virginás a tömegkultúra jellemzése kapcsán további szempontokat is behoz, melyek közül a posztmodern korra (állapotra) jellemzô, médiában áramoltatott reprezentációk / szimulákrumok és azok materiális státuszának kérdése lesz fontos a késôbbi fejezetek számára. Szintén fontos, és a bevezetôben elôkerül, hogy a tömegkultúra meghatározó sajátossága a közérthetôség (a tömegek számára könnyen hozzáférhetô és könnyen érthetố tartalmak kérdésérôl Carroll is hosszan értekezik). A közérthetôség, a könnyú értelmezhetôség azért is kardinális, mert ez az egyik olyan pont, aminek kapcsán a tömegkultúrát a társadalmi rendet és a normákat megerôsítô, konzervatívaffirmatív karakterúnek, és nem utolsósorban kevéssé értékesnek szokás tartani. A fejezet végén Virginás (ezúttal a posztstrukturalizmus, illetve a kritikai kultúrakutatás köréból hozott érvekkel) a tömegkultúra differenciáltabb értelmezési lehetôségeit is hangsúlyozza. Azt, hogy a normaerôsítés mellett azok folyamatos újratárgyalása, sôt akár a szubverzió sem idegen a tömegkultúrától; illetve azt, hogy a tömegkultúra használóit, fogyasztóit korántsem passzív tömegeknek, hanem aktív befogadóknak kell elképzelnünk.

Ezek a tézisek és kérdések természetesen elókerülnek Török Ervin tömegkultúráról írott fejezetében is. Török azzal különíti el egymástól a tömegkultúrát és a populáris kultúrát, hogy azt mondja, ez a két fogalom más-más típusú kérdésekre ad választ, pontosabban eltérô dimenzióban múködik. Ezt követôen részletesen beszél a tömegkultúra kialakulásának körülményeirôl és 
mozgatórugóiról. ${ }^{[4]}$ Az alapos kultúrtörténeti és esztétikatörténeti áttekintés meggyôzô ismeretanyagot mozgat, csakhogy a szöveg egyfelöl rosszul van szerkesztve (nem halad következetesen előre a gondolatmenet), másfelól nyelvileg is túlbonyolított, nehezen követhetô. Ezek az erôsségek és problémák a Török Ervin által írt anyagra általában is jellemzôek, ezért most ennek a szakasznak a hosszabb bemutatásával próbálom megmutatni, mi is a probléma ezzel az érveléssel és szövegszerkesztési, szövegkezelési móddal.

Az alfejezet elsố bekezdése tételmondatként megfogalmazza, hogy a tömegkultúra kialakulásának (pontosabban, a szöveg szerint „magas és populáris (vagy népszerû) kultúra szembeállításának”) melyek voltak a legfontosabb okai. A következő mondat hosszú felsorolása tíz okot sorol fel. A gond abban rejlik, hogy a szöveg a következőkben 1) nem fejti ki szisztematikusan (legalább egyegy mondatban) ezen okok mindegyikét, 2) nem abban a sorrendben haladunk elôre, mint amilyen sorrendben a bekezdés elején az okok szerepeltek, és az sem világos, hogy ezek az okok miképp függenek össze egymással, továbbá 3) nyelvileg is nagyon nehézkes a szöveg.

Egy történeti átalakulást vagy folyamatot ismertető, oksági összefüggéseket áttekintő szakasz esetében a világos érvelés nagyon fontos. Csakhogy a bevezetóben számos olyan okot is felsorol a szöveg, amelyrôl utána említést sem tesz. Ilyen rögtön a legelsô, a szabványosított ipari termelés általánossá válása (pedig a sztenderdizáció a tömegkultúra egyik kardinális összetevôje, és amúgy a kérdés késôbb, a Füzi Izabella által írott fejezetekben is elôkerül). De nincsen szó a társadalmi nyilvánosság átalakulásáról, a múfajok hierarchiájának megkérdôjelezésérôl és a kultúrafogyasztás szegmentálódásáról - pedig ezeket ígérte a tételmondat. Nem többet, legalább egy-egy bôvített mondatot hiányolok, ami kifejtené, megmagyarázná, pontosan érthetôvé tenné ezeket a szempontokat - amúgy épp a tananyag bevezetôjének szellemében, amely kiemelt célként szerepelteti a fogalomtisztázást.

Legalább ennyire zavaró, hogy a gondolatmenet csapongó, és szeszélyesen válogatva, váltogatva ugrálunk a nyitó bekezdésben ígért témák között. A kötelezô iskolai képzés kérdésével kezdünk (ez amúgy a második ok volt, és vastaggal szedve, tehát terminus értékú kifejezésként szerepel). Megtudjuk, hogy ennek következtében bővült ugrásszerúen a potenciális olvasóközönség köre, ami pedig a múvészetekhez kapcsolódó normákat alakította át, és így jutunk el a polgári múveltségeszmény relatívvá válásához (ami a felsorolásban az utolsó, tizedik ok volt). A következô bekezdésekben a múveltségeszmény átalakulásával összefüggố dimenziók (a klasszikus retorika és a szépségfogalom) változásáról van szó, de például vastaggal szedve, kiemelve szerepel a múvészeti sikeresség és az esztétikai értékesség különválása - ami az egyik legfontosabb gondolat, mégsem szerepelt a nyitó felsorolásban. Ahogy a „médiatechnikai változások” sem (kiemelés, vastaggal az eredetiben), pedig ez, a modern nyomdatechnika, az egyik legfontosabb faktor ahogy azt már Virginás Andrea fejezete kapcsán is említettem. Az igazsághoz hozzátartozik, hogy a bevezetô felsorolásban szerepelt a gyorssajtó, csakhogy a kifejtésben akkor vagy ezt a nyomdatechnikai újítást kellett volna rendesen megmagyarázni, vagy helyette egy másik kifejezéssel (mondjuk a modern nyomdatechnika megemlítésével) jelezni ezt a dimenziót. 
A gondolatmenet követését azonban nem csak a kifejtés bizonytalanságai, hanem a megfogalmazások nehézkessége is zavarja. Ennek példázására egyetlen bekezdést kell teljes terjedelemben beidéznem:

Amikor a múvészetekre a tömegmédiumokhoz füződô viszonya felôl, és ezzel egybefüggően az olvasói figyelem fenntartásának a XIX. században, sốt korábban elkezdôdött standardizációs folyamata felól kérdezünk rá, akkor a kérdés bizonyos értelemben közömbös azokra az esztétikai-filozófiai paradigmákra, amelyek mentén az autonóm múvészeti mezôben résztvevôk a múvészeti folyamatok diakróniáját, azaz tartamát és változó perspektíváját értelmezték. Ha a terjesztési médiumok felól vizsgáljuk a múvészeteket, vagyis arra vagyunk kíváncsiak, hogy a médium hogyan hat vissza az alkotások formájára, milyen standardizációs feltételek mozdították elô ezek megjegyezhetôségét és követhetôségét, az olvasói figyelem megszerzését és fenntartását, hogyan alakultak ki olyan zsánerek és stilisztikai alakzatok, amelyek a sémaképzôdés és sématörés nagyobb rendszereit létrehozták, akkor nem a múvészeti alkotások szinguláris teljesítményeinek a körülményeire, hanem olyan „evolúciós” folyamatokra kérdezünk rá, amelyek legfeljebb csak részlegesen vehetik figyelembe az egyes alkotások hatás- és recepciós összefüggéseit. Itt a hangsúly ugyanis a nézôi tekintet bevonásának, valamint élményközösség-szervezô múködésének a mikéntjére esik, továbbá a mintaképződésekre és azok mediális alapjára, vagyis nem annyira azok esztétikai ítéletek mentén történó artikulációja az érdekes. „Magas” és „tömegkultúra” fogalmainak kölcsönös irritációja fogalmi alapjaik ilyen különbözôségeiból is következik.

Hosszú mondatok, bonyolult mondatszerkezetek, sok idegen szóval. Nem biztos, hogy ez az, ami a „célközönség” igényeinek leginkább megfelel. (Célközönségnek jelen esetben a szöveg által megjelölt, osztatlan tanári képzés hallgatóit tekinteném, de az alapszakos szabadbölcsész hallgatókat is ide számíthatjuk.)

Török fent említett érvelô szövegében az egyes okok kifejtettsége aránytalan, az oksági láncolat logikai rendje nem egyértelmú, és a megfogalmazás is nehézkes. Az olvasó számára mindez erôs kihívást jelent - márpedig egy oktatási tananyag esetében ezek a szempontok (érthetôség, következetes érvelés) korántsem mellékesek.

\section{Múfajok nyomában}

A tömegkultúrával kapcsolatos kérdések mellett természetesen megkerülhetetlen mindegyik tananyagban a múfajisággal kapcsolatos ismeretek rendszerezése. Virginás egyszerú oppozíciós logikával élve a múfaji filmeket egyfelól besorolja a tömegkultúra ernyôje alá (30), másfelôl szembe állítja ôket a múvészfilmekkel. Ez az oppozíció (ahogy a leegyszerúsítô ellentétpárokban való gondolkodás általában) elég szerencsétlen (és a szerzố tanulmányaira amúgy messzemenôkig 
nem jellemzô), de tulajdonképpen itt csak a kulturális kánonok szerveződésének dinamikáját kívánja jelezni. Zavaróbb, hogy a filmmúfajok értelmezésével kapcsolatban egy fontos állítást vagy attitúdöt rossz struktúrában, részben nem releváns példákkal fejt ki. Maga az állítás annak kiemelése, hogy a filmmúfajok nem esszenciális természetúek. A szöveg tehát azt kívánja bemutatni és érvekkel alátámasztani, hogy a múfajok nem eredendôen, öröktôl valók, hanem különbözố kontextusokban eltérô módon születnek és teremtődnek meg. Virginás öt, jól elkülönített regisztert, a filmmúfajok öt értelmezési kategóriáját mutatja be. Ezek a következôk: 1) a producerek, filmkészítôk fejében lévô elgondolások, 2) a filmet készítô stáb elképzelései az adott múfajról, 3) a nézók elvárásrendszere, 4) a terjesztôk és marketingesek szempontjai, és 5) a már kész filmekbốl leszûrhetô múfaji sémák.

Ez az öt regiszter vagy aspektus valóban jól elkülöníthetố egymástól, tehát a tipológia múködik (és használják is a különbözố múfajelméleti munkák). Csakhogy Virginás kifejtésében az egyes kategóriák elnevezése félrevezetô, és az ismertetések sem elég szabatosak. Egy javított lista valahogy így nézne ki: 1) a gyártási-intézményi szereplôk múfajkonstruáló tevékenysége, 2) a filmkészítôk elgondolásai, 3) a befogadók elôzetes elvárásai, illetve a nézókre gyakorolt hatás alapján felállítható múfajtipológia, 4) a terjesztốk intézményi-múfajkonstruáló munkája, 5) a kritikai recepció és a rajongói kultúra. Virginás tehát leírja azt a dinamikát, ahogy a múfajiság, a múfaji elgondolások, a múfajokkal kapcsolatos elvárások, a múfajok rendszerteremtő és rendszerezố funkciója végigkíséri a filmkultúrát annak teljes körében, azaz a gyártástól a forgalmazásig, bemutatásig és a fogadtatásig mindenütt jelen van (majd ezen keresztül, visszahatva, ezek az aspektusok egymást is befolyásolják). Csakhogy az elsô pontban hozott példája (az Elfújta a szél készítéstörténete) épp nem a rendezôk elképzeléseire, hanem a produkciós, gyártói, ipari stúdiószemléletre lehet jó példa. A második pontban, amikor elvileg a stáb hatásáról és elképzeléseirôl akar beszélni, talán nem véletlenül hoz megint csak más szempontból, mégpedig az alkotói-rendezôi oldal meghatározó szerepét bemutató példát (Lynch és a Trwin Peaks , illetve a Mulholland Drive esete).

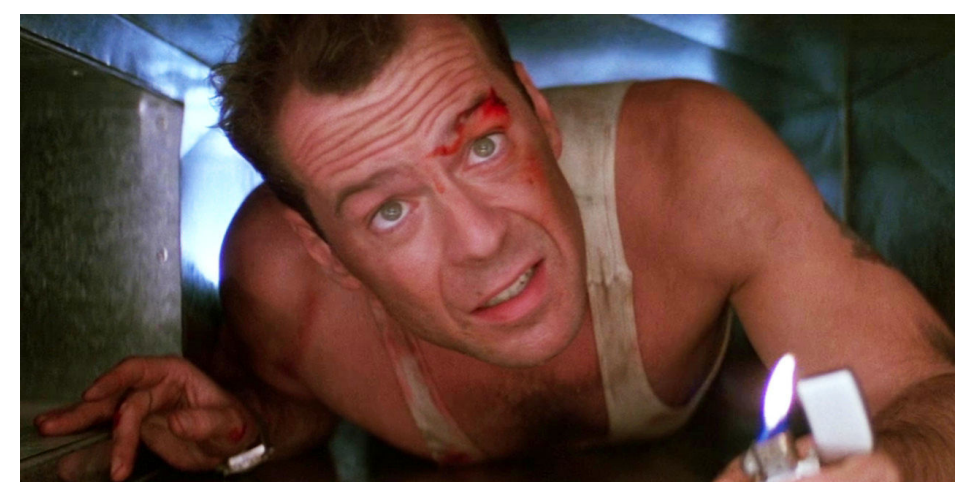

Drágán add az életed (Die Hard. John McTiernan, 1988) 
Itt is világosan látható, hogy mennyire fontosak a jól megválasztott példák és a világos érvelés. A marketing fontossága nem kérdés, az viszont, hogy ezt az aspektust valóban egy oldal hosszan kell filmplakátok ismertetése segítségével illusztrálni, miközben a korábbi kategóriák esetében feleekkora terjedelmet sem kaptak a példák, nos, az már nem egyértelmú. [5]

A múfajelmélettel kapcsolatos vonatkozások sokkal kompaktabb módon és szemléletesen kerülnek elô Füzi Izabella anyagában. Itt ugyan csak egyetlen fejezet (a klasszikus narratívával foglalkozó rész) egyetlen alfejezete foglalkozik a múfaji vonatkozásokkal, ám pontosan meg van választva, hogy mi az érdekes (a múfajok tömegkulturális funkciója, a társadalmi rendhez való viszony - így lesz fontos Thomas Schatz rendszere), és világosan, táblázatba is szedve kerülnek elố a különféle szempontok. ${ }^{[6]}$

\section{Digitális térben}

A harmadik kérdés, amelynek mentén összevethetô a két tananyag, immáron egyértelmúen a kortárs filmkultúrához kapcsolódik, és ez a digitális technológia hatása az elmúlt idôk filmesmozgóképes trendjeire. Virginás könyve lényegében teljes egészében erre a problémára van felfüzve, és ez is az egyik erôssége a kötetnek: jól használható áttekintést és bevezetést nyújt az analóg-digitális átmenet kontextusaiba (különösen a könyv 3. fejezete, a Tömegfilm és a technikai médiumok). Itt Virginás elegánsan haladva, évtizedról évtizedre áttekinti a tömegfilm és a digitális technológia találkozásának különféle színtereit (a filmkészítéstôl a forgalmazásig, bemutatásig és a filmek használatba vételének különböző egyéb platformjaiig), majd két dimenziót kiemelve mutatja be rövid filmelemzések segítségével a digitális átmenet narratívát és képformálást egyaránt befolyásoló hatásait. A számítógépek filmes narratívákban való szerepeltetésével foglalkozó áttekintés nem olyan revelatív, bár a technológiai vonatkozások okán érthetô a szerepeltetése. A másik alfejezet, amely a testek megjelenítésével, jelenlétével és a testi fordulat digitális vonatkozásaival foglalkozik, már érdekesebb, és meg is vannak a kapcsolódási pontjai a könyvben (az egyik bevezetô fejezet a társadalmi nem kérdését tárgyalja, az utolsó blokk filmelemzései pedig meghurcolt, sok szenvedést átélt női hősnốk történeteivel és testeivel foglalkoznak).

A tömegfilm, a narratíva és a digitális technológia kérdése Füzi Izabella anyagában is külön alfejezetet kap. Itt, mivel az elbeszélés (átalakulásának) kérdése áll a középpontban, érthetôen a narratíva vs. látvány oppozíció lazítása és differenciálása a legfontosabb kérdés. Ezek a fejezetek rövid, de jól fókuszált összefoglalást nyújtanak, de - tekintve, hogy ezekben a témákban az elmúlt idôben szerencsére igen sok releváns és az oktatásban is jól használható publikáció jelent meg [7] igazán az összefoglaló és lényegkiemelô funkciójuk a fontos. 


\section{Példaadók}

A két tananyag érdekesen különbözik egymástól abban, ahogy a filmpéldákat, elemzô illusztrációkat, esettanulmányokat használják. Amíg Virginás Andrea kötete (a zárófejezetet leszámítva, amely lényegében csak film- és karakterelemzésre koncentrál) a teoretikus-történeti áttekintésekbe illeszt be sok rövid példát, Török Ervin és Füzi Izabella tananyaga külön, önálló fejezetként beépülô esettanulmányok segítségével mutatja be a tanultak-tanítottak alkalmazását. (Természetesen ettól még az ô szövegeikben is szerepelnek illusztráló bekezdések és rövid, példaszerú elemzések - legyen az egy Petôfi-vers vagy a Drágán add az életed és a kortárs látványfilm példája.) Nekem mindkét megoldás szimpatikus: az önálló esettanulmányok nagyobb teret tudnak biztosítani a megelőző fejezetekben ismertetett fogalmak értelmezô használatára; a beékelt rövid példák pedig szemléletessé tudják tenni a gyorsan, röviden ismertetett téziseket.

Tanulságos azonban, hogy milyen körből, honnan valók a példák - milyen a megoszlásuk, egyáltalán szempont-e az, hogy az esettanulmányok és/vagy a példák önmagukban, illetve együtt is beszédesek legyenek? Török Ervin tananyagában a populáris irodalom narratív-múfaji lehetôségei kapcsán kerül elő három múfaj, és azokhoz kapcsolva három esettanulmány. A példaelemzések közül az elsô, egy Jules Verne-regény a sci-fi múködését, a második (a kortárs svéd krimiíró, Håkan Nesser $A$ gonosz arcai címú kötete) a krimi mechanizmusait, míg a Bridget Jones-könyvek, illetve a Terézanyu és Parti Nagy Lajos Ibusárja a szingliregény és az „újrahasznosított” lektû́r variációit mutatja be. A három múfaj jól hozza az eltérô pólusokat a társadalmi normához és a társadalmi képzelethez fúzôdô, radikálisan eltérô viszonyaik miatt (ahogy arról már érintôlegesen a Schatz-féle rendszer kapcsán szó volt). Eléggé ismertek (legalább brand-szinten mint „skandináv krimi”), de nem túlhasználtak - és alapos elemzéseik jól tudják példázni az elméleti tananyagot.

Füzi Izabella anyagában két film és egy televíziós sorozat kiemelt elemzése szerepel. Capra Az élet csodaszép és Marc Foster Felforgatókönyv címú filmje, illetve a 24 címú amerikai televíziós sorozat. A Capra-film, illetve a Fox tévétársaság paradigmateremtô politikai thrillerje nagyon ismert, de eléggé magától értetôdô a klasszikus elbeszélés, illetve a kortárs tömegfilmestömegkulturális elbeszélés módozatainak - Foster filmje elsőre kilóg a sorból. A három példát azonban a narratív komplexitás kérdése mégiscsak összeköti - annak egy korai-klasszikus, egy kortárs filmes-posztklasszikus és egy kortárs tévés esetét láthatjuk. ${ }^{[8]}$ Ha azonban ez a kapcsolat megvan, akkor talán érdemes lett volna minderre a szövegben is reflektálni - legalább a narratív komplexitással foglalkozó alfejezetben.

\section{Végül}

A magyar nyelvú filmes-mozgóképes (felsô)oktatási segédanyagok piaca túltelítettnek korántsem 
mondható, nagyon jó tehát, ha új kötetek és szövegek jelennek meg. A most bemutatott két jegyzet / segédanyag / tananyag azonban nem rendezi át radikálisan a terepet. Füzi Izabella tömegfilmes elbeszéléssel foglalkozó része a legkiegyensúlyozottabb - érvelésében, gondolatmenetében, az információk arányos adagolásában és nyelvezetében egyaránt. Virginás Andrea könyve nagyon ambíciózus, de sok hiányérzetet hagy maga után. Alapvetôen amiatt, hogy az anyag rendkívül felemás és eklektikus, fôképp kifejtésmódjában, de olykor megfogalmazásaiban is. Vannak nagyon jól megírt, világos gondolatvezetésú összefoglalások benne (mint a már említett fejezet a tömegfilm és a technikai médiumok átalakulásáról a digitális korszakban), akadnak korábban publikált szövegek részben átírt, átigazított változataira épülő fejezetek (ilyen az európai és a hollywoodi filmkultúra között ingázó rendezôk pályáját kiindulópontként vevô múfaji elemzések, illetve a kötetet záró elemzés), és vannak kevéssé kidolgozott, nem jól megformált vagy megfogalmazott áttekintések (a bevezetô tömegfilm és tömegkultúra fejezet vagy a filmmúfajok rendszerezése). ${ }^{[9]}$ Török Ervin tananyaga hatalmas mennyiségú, szisztematikus tudást, információt és ismeretet kíván átadni, de gyakran olyan körülményes és nehézkes nyelvezettel teszi, hogy félek, már félúton elveszítheti sok olvasóját. Egy szigorú szerkesztô és egy figyelmes olvasószerkesztô mindkét szöveggel csodákat tehetett volna. Ennek hiányában azonban a lehetségesnél (és szerintem az ideálisnál) nagyobb teher nehezedik ezen tananyagok megcélzott, potenciális, kedves olvasójára (hallgatójára, nézôjére).

Ezek a felemásságok összességükben azért eléggé zavaróak. Ezért bármennyire is örömteli egyszerre két új oktatási segédanyag megjelenése, inkább csak néhány fejezetükkel, bizonyos részleteiket kiemelve tûnnek igazán használhatónak, más egyetemek kurzusaiba illeszthetônek. Ez sem kevés persze, és tekintve, hogy milyen széles spektrumot fognak át ezek a tananyagok, a következő években várhatóan rengeteg diák és tanár fogja élesben tesztelni ôket. Ennek köszönhetôen pedig a tömegfilm a magyar egyetemi tömegoktatásban is megérkezik majd a tömegkultúrába.

\section{Jegyzetek}

1. A szerzôpáros tíz évvel ezelôtt írt Bevezetés az epikai szövegek és a narratív film elméleteibe (Szeged, 2006) címú, szintén online elérhetô tananyaga sok szempontból elôképe vagy természetes párja a mostani munkának.

2. Érdekes, hogy a tömegfilm és a tömegkultúra kiemelkedô hazai teoretikusa, Király Jenô neve csak érintôlegesen kerül elô a két tananyagban, és érdemben egyik sem mutatja be Király eredeti és monumentális elméletét.

3. Carroll, Noël: A Philosophy of Mass Art. Oxford, Clarendon Press, 1998.

4. A tömegkultúra kialakulásának legfontosabb mozzanatait Virginás is felsorolja, de az ô könyve alapvetôen a tömegkultúra és a tömegfilm kortárs dinamikájával foglalkozik.

5. A plakátokat elemzô rész amúgy Virginás egyik korábbi, online is elérhetố cikkébốl származik. Az újrafelhasználás ugyan érhetô, de azért egy kicsit felesleges és zavaró is, mert megzökkenti a szöveg kifejtését, arányos elôrehaladását.

6. Füzi anyaga három alfejezetben tekinti át a klasszikus narratíva filmelméleti megközelítéseit. Ezek közül messze a múfajelméleti rész a legerôsebb, másik kettô (a kritikai elméletekkel, illetve a kognitív-formalista 
elméletekkel foglalkozó rész) sokkal rövidebb és elnagyoltabb. Ha már ezek a vonatkozások bekerültek az anyagba, akkor érdemesebb lett volna valamivel bóvebb terjedelmet szentelni nekik, mert például a kritikai elméletek kapcsán szinte csak a varratelméletrôl van szó, valamint érintôlegesen kerül elô a feminizmus és Laura Mulvey. Tény, hogy mindezen kérdésekrôl magyarul is akad elérhetô irodalom, de ez az aránytalanság ettôl még zavaró.

7. Az Apertúra hagyományosan erôs a digitális (film)kultúrával foglalkozó szövegek publikálásában. Füzi összefoglalása értelemszerúen ezekre, illetve a külön e-könyvben is megjelentetett „Dragon-Sághy” vitában elhangzottak szintetizálására épül. http://digitalculture.hu/publikaciok/dragon-saghy/

8. Füzi szövege nem a narratív komplexitás, hanem a komplex narratívák formulát használja. A tévésorozatok bevonása a tananyagba (ha csak egyetlen téma erejéig is) a tömegfilm tömegkultúrán belüli kapcsolatait, kapcsolódási pontjait tudja érzékletesen példázni. Itt is akad azonban egy fontos, említetlen magyar nyelvú szakirodalmi tétel, mégpedig a Thomka Beáta szerkesztésében megjelent Narratívák könyvsorozat Narratív televízió címú kötete (melynek szerkesztői elôszava ráadásul online is elérhetô). Kiss Gábor Zoltán (szerk.): Narratív televizió. Budapest, Kijárat Kiadó, 2014.

9. Virginás sokszor olyan szövegekre is eredeti verzióban hivatkozik, amelyek elérhetók magyarul. Ilyen például Jamesontól A posztmodern, avagy a kései kapitalizmus kulturális logikája (egy korábbi, rövidített kiadás után a teljes szöveget a Noran Libro jelentette meg 2010-ben). De két olyan kulcstanulmány is elérhetô magyarul, mint Bordwellnek a kortárs amerikai filmek vizuális stílusáról írott elemzése, illetve Thomas Elsaesser esszéje az elmejátékfilmekről. (Egyébként mindkettô szerepel, magyar verzióban, Füzi Izabella anyagának szakirodalmában.)

\section{Irodalomjegyzék}

- A film jövóje a digitalizáció korában. Adatbázis és/vagy narratíva? (A Dragon-Sághy vita). Szerk. Gollowitzer Diána. Szeged, Digitális Kultúra és Elméletek Kutatócsoport, Szegedi Tudományegyetem, 2012. URL: http://digitalculture.hu/publikaciok/dragon-saghy/

- Bordwell, David: Intenzív folyamatosság. Vizuális stílus a kortárs amerikai filmben. Ford. Andorka György. Metropolis, 2012/4. 48-65.

- Carroll, Noël: A Philosophy of Mass Art. Oxford, Clarendon Press, 1998.

- Elsaesser, Thomas: Az elmejátékfilm. Ford. Fábics Natália. Metropolis, 2012/2. 8-29.

- Füzi Izabella - Török Ervin :Bevezetés az epikai szövegek és a narratív film elméleteibe. Szeged, 2006.

- Füzi Izabella - Török Ervin: Elbeszélés a tömegkultúra korában. Digitális tananyag. Szeged, 2016

- Jameson, Fredric: A posztmodern, avagy a kései kapitalizmus kulturális logikája. Ford. Dudik Annamária Éva. Budapest, Noran Libro, 2010.

- King, Geoff: Látványosság, elbeszélés és a látványorientált hollywoodi blockbuster. Ford. Andorka György és Simor Eszter. Metropolis, 2012/4. 8-19.

- Kiss Gábor Zoltán (szerk.): Narrativ televízió. Budapest, Kijárat Kiadó, 2014.

- Virginás Andrea: A kortárs tömegfilm (tömegkultúra, múfajok, médiumok) - Egyetemi jegyzet. Kolozsvár, Ábel Kiadó, 2016. 


\section{Filmográfia}

- 24 (Joel Surnow és Robert Cochran, 2001-2010)

- Az élet csodaszép (It's a Wonderful Life. Frank Capra, 1946)

- Drágán add az életed (Die Hard. John McTiernan, 1988)

- Elfújta a szél (Gone with the Wind. Victor Fleming, 1939)

- Felforgatókönyv (Stranger Than Fiction. Marc Forster, 2006)

- Mulholland Drive - A sötétség útja (Mulholland Dr. David Lynch, 2001)

- Trin Peaks (Mark Frost, David Lynch, 1990-1991) 
(C) Apertúra, 2017. Ỗsz | www.apertura.hu

webcím: https://www.apertura.hu/2017/osz/varga-filmek-tomegek-kulturak-ket-uj-oktatasi-

segedanyagrol//

https://doi.org/10.31176/apertura.2018.13.1.12

\section{(2)opertúro}

